\title{
GAMETOGENESIS IN MADRACIS DECACTIS LYMAN, 1859 (CNIDARIA, SCLERACTINIA) FROM ILHA GRANDE BAY (RIO DE JANEIRO), SOUTHEASTERN BRAZIL
}

\author{
Daniela Muramatsu* and Fábio Lang da Silveira \\ Instituto de Biociências da Universidade de São Paulo \\ Departamento de Zoologia \\ (Rua do Matão, travessa 14, 321, 05508-900 São Paulo, SP, Brasil) \\ *dmuramatsu@yahoo.com
}

\begin{abstract}
Collections were made every two months in Ilha Grande Bay, Rio de Janeiro, for 21 months (August/2004-May/2006) to study the gametogenesis of Madracis decactis Lyman, 1859. A total of 1800 polyps were examined using standard histological techniques. Madracis decactis is a hermaphroditic species whose male and female gametes develop within different mesenteries. Oogenesis begins in October, while spermatogenesis begins at the end of February, both reaching maturity at the end of April. The peak of reproductive activity occurred between February and April, when all the polyps were fertile, containing mainly stage III oocytes. Examination of fertile polyps indicated the simultaneous presence of stages I, II and III for oogenesis and I, II, III and IV for spermatogenesis. No embryos or planulae were observed in the histological sections. The gametes or planulae spawning may occur between April and May.
\end{abstract}

\section{RESUMO}

Coletas foram feitas a cada dois meses na Baía de Ilha Grande, Rio de Janeiro, durante 21 meses (agosto/2004 - maio/2006) para estudar a gametogênese de Madracis decactis Lyman, 1859. Um total de 1800 pólipos foram examinados através de técnicas histológicas padrão. $M$. decactis é uma espécie hermafrodita, cujos gametas masculinos e femininos se desenvolvem em mesentérios diferentes. A ovogênese iniciou em outubro, e a espermatogênese no final de fevereiro, ambas alcançando maturidade no final do mês de abril. O pico da atividade reprodutiva ocorreu entre fevereiro e abril quando todos os pólipos estavam férteis contendo, principalmente, ovócitos no estágio III de maturação. O exame dos pólipos férteis indicou a presença simultânea dos estágios de desenvolvimento I, II e III para a ovogênese e dos estágios I, II, III e IV para a espermatogênese. Não foram encontrados embriões ou plânulas nos cortes histológicos. Os dados indicam que a liberação dos gametas ou plânulas deve ocorrer, provavelmente, entre os meses de abril e maio.

Descriptors: Cnidaria, Scleractinia, Madracis decactis, Gametogenesis, Reproductive cycle.

Descritores: Cnidaria, Scleractinia, Madracis decactis, Gametogênese, Ciclo reprodutivo.

\section{INTRODUCTION}

During the last two decades, the research into Brazilian reef communities became particularly active, at the same time as the pressures on and threats to these environments have also increased (LEÃO et al., 2003). Studies on the reproductive biology of Brazilian scleractinian corals began in the last years of the $20^{\text {th }}$ and the first of the $21^{\text {st }}$ centuries (PIRES et al., 1999, 2002; CALDERON et al., 2000; FRANCINI et al., 2002; NEVES; PIRES, 2002; PIRES; CAPARELLI, 2002; LINS DE BARROS et al., 2003; NEVES; SILVEIRA, 2003; CASTRO, B.T.; PIRES,
2006). The reproductive biology of 8 out of 16 zooxanthellate coral species has been studied, especially on the Abrolhos Reef Complex, Bahia State, the largest and richest coral reef in the South Atlantic (CASTRO, C. B.; PIRES, 2001). The duration of the gametogenesis cycle and the period of gametes/planulae spawning vary widely between species on the Abrolhos Reef Complex. This variation in the reproductive patterns between species of the same geographical region indicates that if exogenous factors determine the reproductive timing and seasonality, they may be species-specific (HARRIOTT, 1983; BABCOCK et al., 1986). 
Sea surface temperature (SST) plays a fundamental role in controlling reproductive seasonality (OLIVER et al., 1988). However, many recent studies on coral reproduction and their relationships with SST have indicated that other factors (such as solar insolation, rainy season and photoperiod) may also influence the reproductive activity of these animals. Some studies have demonstrated that the time of spawning is related to solar insolation, while others have suggested that the time of coral spawning is controlled by a combination of SST and rainfall (MENDES; WOODLEY, 2002 PENLAND et al., 2004; VAN WOESIK et al., 2006).

Madracis decactis and Porites astreoides together have the widest geographical distribution among the Brazilian zooxanthellate species: from Parcel do Manuel Luiz, Maranhão State in the north to the southern state of Santa Catarina (CASTRO; PIRES, 2001). M. decactis does not occur in the region of Cabo Frio, state of Rio de Janeiro, but it is very common at shallow depths $(2-5 \mathrm{~m})$ in Ilha Grande Bay, RJ $\left(23^{\circ} \mathrm{S} ; 44^{\circ} \mathrm{W}\right)$ (LABOREL, 1969/70); this species and Mussismilia hispida Verrill, 1901 are the only two zooxanthellate species that occur in this region.

The present study was designed to analyze the sexual pattern (gonochoric/hermaphroditic) and the mode of reproduction (gametes spawning/planulae release), by describing gametogenesis and establishing the probable period of planulae or gamete spawning.

\section{Material And Methods}

Species

Madracis decactis from Ilha Grande Bay has an incrusting or nodular colonial form, with a diameter of less than $30 \mathrm{~cm}$ (Fig. 1). The colonies are dark brown, purple or dark green in color, with small corallites (1-2 mm in diameter). Nodular colonies are usually found in well-illuminated locations, while the incrusting forms are found on more cryptic vertical substrates.

\section{Collections and Histological Procedures}

Collections were made every two months from August 2004 to May 2006 on Imboassica Island

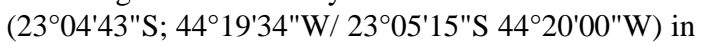
Ilha Grande Bay. During each collection, 12 small unattached colonies were collected at 5-7 m depth by SCUBA diving. The samples were fixed in $10 \%$ formaldehyde in seawater for 2-3 months. The material was decalcified with $10 \%$ formic acid solution and rinsed in fresh water for 24 hours. Histological sections were made following Pires et al. (1999) and Neves and Pires (2002). The coral tissue was arranged so that polyps could be sectioned transversely. Sections $7 \mu \mathrm{m}$ thick were obtained at $200 \mu \mathrm{m}$ intervals using a manual microtome,

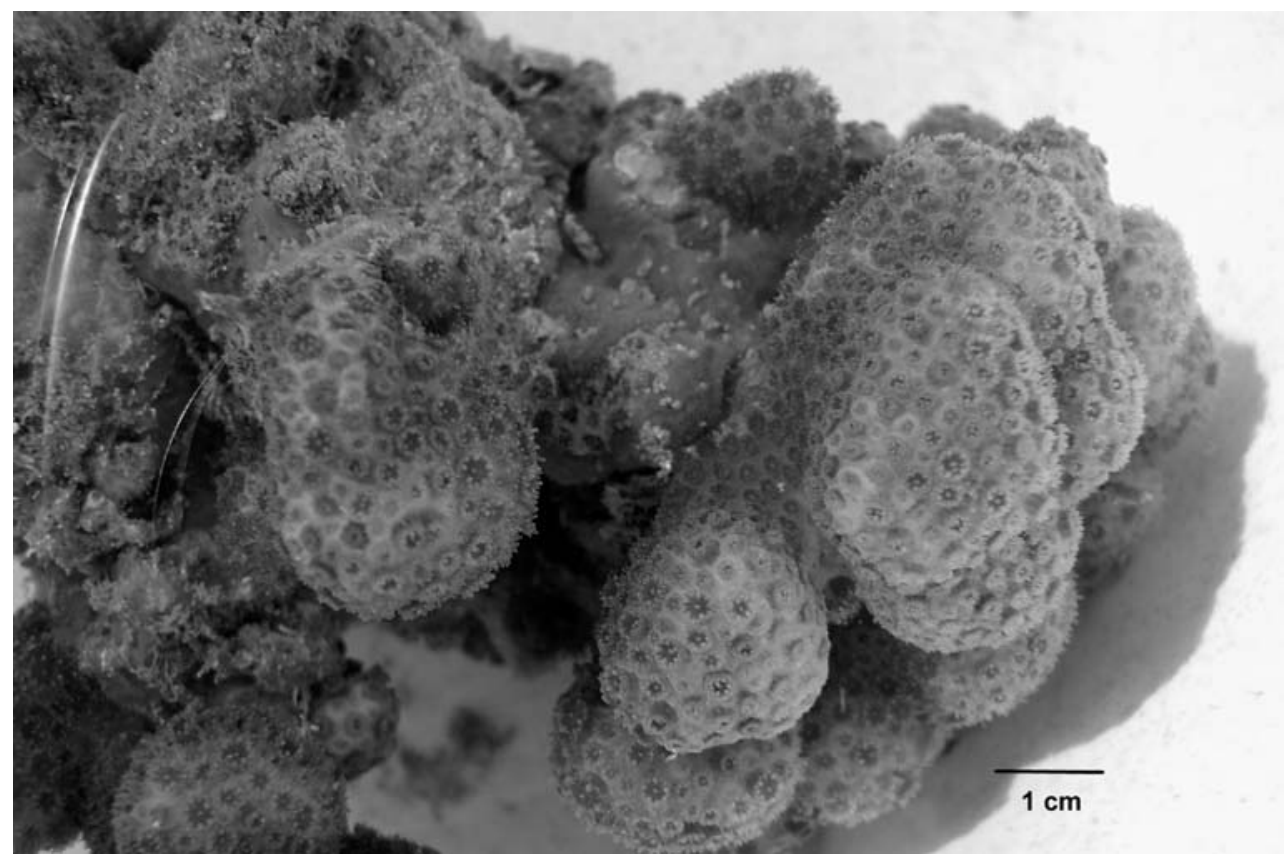

Fig.1. Colony of Madracis decactis sampled on 23 July 2006 at Imboassica Island, Ilha Grande Bay, Rio de Janeiro, Brazil. 
producing 3 to 6 sections/polyp. The tissue was stained with Weigert's Hematoxylin and Mallory's Trichrome. From each colony we selected 10 to 16 polyps that all had undamaged mesenteries to assess the presence of spermaries and ovaries. The number and size (longest and shortest axes) of the oocytes' cytoplasm and nuclei and spermaries were only recorded when nucleoli were present; the developmental stages of the gametes were defined based on Szmant-Froelich et al. $(1980,1985)$ and Glynn et al. (1994).

\section{Environmental Parameters}

Data for sea-surface temperature (SST) were derived from the National Operations Model Archive and Distribution System (NOMADS) developed by the National Oceanic and Atmospheric Administration (NOAA). The SST data set was accessed using the NOMADS Live Access Server available online (http://nomads.ncdc.noaa.gov:8085/las/servlets/dataset) and compiled as monthly means over a 21 -year period (1985-2006).

Monthly means over a 10-year period (19831993) of solar insolation were obtained from Surface Meteorology and Solar Energy (http://eosweb.larc.nasa.gov/cgi-bin/sse/sse.cgi?) sponsored by the National Aeronautic and Space Administration (NASA).

Data for rain spatial distribution in the Ilha Grande Bay region were obtained from Soares et al. (2005). Thirty-one pluviometric stations provided annual means of precipitation from 1970 to 1999. Additional data were obtained from the Plano de Manejo de Manejo do Parque Nacional da Serra da

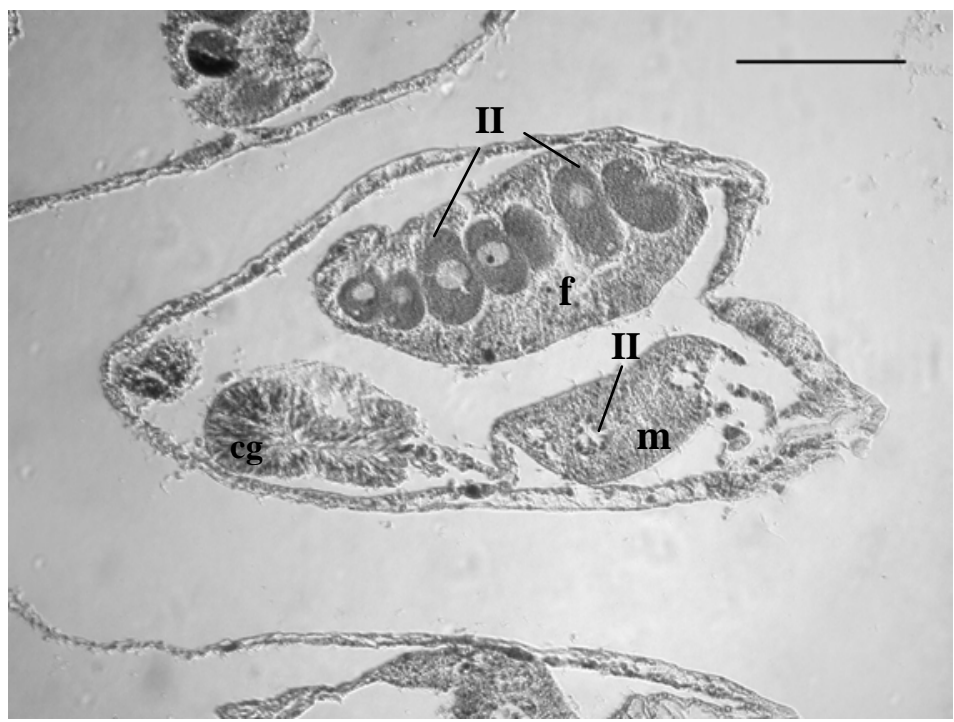

Bocaina (Brasil, 2000) which provided information based on the measurements of DAEE (Divisão de Águas e Energia Elétrica do Estado de São Paulo) and INMET (Instituto Nacional de Meteorologia) weather stations.

\section{RESUlts AND Discussion}

\section{Sexuality}

$M$. decactis is a hermaphroditic species, whose polyps bear ten gastric loculi with a pair of mesenteries each: the female mesentery, shorter and lacking a cnidogladular region at the end; and the male mesentery, longer with a well-developed cnidoglandular region (Fig. 2). Hermaphroditism and the gonads in separate mesenteries agree with the pattern observed in the species of the Abrolhos Reef Complex (see Castro, B. T. and Pires, 2006) and seem to be very conservative at the family level (HARRISON, 1985; SCHLESINGER et al., 1998). However, Vermeij et al. (2004) observed in $M$. decactis from the Caribbean region that each polyp had only ten fertile mesenteries, $50 \%$ of them with male and female gametes developing together in the same mesentery. Morphological and genetic comparisons would be necessary to ascertain whether these are the same species, or whether there is intraspecific variation in a few characteristics between the two localities, including the number of fertile mesenteries and gonadal arrangement, as well as divergences in the mode of reproduction (HARRISON, 1985).
Fig. 2. Transversal section of a loculus with female mesentery (f) containing oocyte III, a male mesentery (m) containing spermary II and the cnidogladular region in its end $(\mathrm{cg})$ (scale: $100 \mu \mathrm{m}$ ). 
Gametogenesis Stages

Three developmental stages for oocytes and four for spermaries were defined, based on SzmantFroelich et al. (1980, 1985) and Glynn et al. (1994) (Table 1). It was difficult to distinguish the oogonia stage of the interstitial cell, but the other oocyte stages were easier to distinguish because of their larger size, well-defined limit and typical blue cytoplasm. The nuclei/cytoplasm ratio decreased as the oocyte developed (oocyte I: $0.73 \pm 0.02$; oocyte II: $0.59 \pm 0.02$; oocyte III: $0.41 \pm 0.04)$. The spermatogonia were always grouped in clusters surrounded by a thin mesogleal layer, making them easier to distinguish. As the spemaries developed, the number of spermatocytes increased. Spermary stage III had almost all the spermatocytes concentrated at the periphery, forming a lumen in the center of the spermary. The spermatocyte size changes were indistinguishable, being evident only in the spermatozoid stage.

\section{Mode of Reproduction}

No embryos or planulae were observed in the histological sections. The absence of these developmental stages and the lack of the gametes have been suggested, in other studies, as evidence of the gamete spawning mode of reproduction (KOJIS; QUINN, 1981; SOONG, 1991; SIER; OLIVE, 1994). However, the absence of embryos and planulae in the histological sections is not always a proof of the spawning mode of reproduction, because these stages can remain for a short period inside the polyp (STIMSON, 1978; HARRIOTT, 1983). Vermeij et al. (2003) captured planulae of Madracis species, including $M$. decactis, using nets positioned around the colonies, but did not observe planulae in the more than 8000 histological sections examined (VERMEIJ et al., 2004). The authors suggested that these species were "quick releasers" because of the rapid release of embryos after fertilization.

At the end of the reproductive cycle, the polyp sections showed gastric loculi nearly filled with developing gametes (Fig. 3). At this stage, it is probable that little or no heterotrophic feeding occurs (HARRISON; WALLACE, 1990). Because of the small size of the polyps, it is possible that the embryos (or gametes) are released quickly to make space available for the development of new embryos (VERMEIJ et al., 2004).

Table 1. Gametogenesis stages based on Szmant-Froelich (1980, 1985) and Glynn et al. (1994).

\begin{tabular}{|c|c|c|}
\hline Stage & Spermaries & Oocytes \\
\hline I & $\begin{array}{l}\text { Spermatogonia with } 2.4 \text { to } 4.8 \mu \mathrm{m} \text { in diameter, } \\
\text { elliptical form arranged in cluster surrounded by a } \\
\text { thin mesogleal coat. Spermatocyte I with size and } \\
\text { color similar to the spermatogonia, but forming } \\
\text { spermaries with a more well defined mesoglea } \\
\text { layer }\end{array}$ & $\begin{array}{l}\text { Oogonia with large nuclei of light blue or no color, } \\
\text { nucleoli and cytoplasm not evident. Oocyte I near the } \\
\text { mesoglea with nuclei and cytoplasm light blue and } \\
\text { nucleoli red. Cells from } 2.1 \text { to } 6.75 \mu \mathrm{m} \text { in diameter }\end{array}$ \\
\hline II & $\begin{array}{l}\text { Spermaries presenting a vacuolated aspect in the } \\
\text { central region filled with few spermatocyte. } \\
\text { Maximum diameter of } 47.25 \mu \mathrm{m}\end{array}$ & $\begin{array}{l}\text { Oocyte of } 4.5 \text { to } 13.5 \mu \mathrm{m} \text { in diameter with spherical or } \\
\text { elliptical form, light blue cytoplasm with a centralized } \\
\text { nuclei and a red or orange nucleoli }\end{array}$ \\
\hline III & $\begin{array}{l}\text { Bigger spermaries with a longer and more } \\
\text { elliptical form, filled with dark blue, wine, } \\
\text { brown or orange spermatocytes arranged on the } \\
\text { spermary's periphery. Lumen present. Maximum } \\
\text { diameter } 107 \mu \mathrm{m}\end{array}$ & $\begin{array}{l}\text { Oocyte with elliptical form, well developed cytoplasm } \\
\text { of blue or grayish color, lipid vesicles present, } \\
\text { centralized nuclei with a very evident pink or red } \\
\text { nucleoli. In a more mature stage, many yolk grains in } \\
\text { the cytoplasm. Cells of } 11.1 \text { to } 108.75 \mu \mathrm{m} \text { diameter }\end{array}$ \\
\hline IV & $\begin{array}{l}\text { Spermaries with wine spermatozoa with blue tail. } \\
\text { Typical bouquet arrangement occasionally } \\
\text { observed }\end{array}$ & \\
\hline
\end{tabular}


However, to confirm the exact reproductive mode of $M$. decactis, it would be necessary to observe embryos or planulae in the histological sections or to observe the planulation directly to be sure that the species from Ilha Grande Bay broods its planulae, because this characteristic can vary intraspecifically, as observed in other species of the genus Pocillopora, which can spawn gametes, brood planulae or both (GLYNN et al., 1991; TANNER, 1996; WARD, 1992).

\section{Reproductive Cycle}

The reproductive cycle of $M$. decactis lasted about seven months. The first oocytes were observed at the beginning of October (Fig. 4). Almost all stages were observed simultaneously, indicating continuous oocyte production. At the end of the cycle (April) there was a synchronization of the oocyte maturation. The spermatogenesis was shorter (lasting three months), beginning in February and reaching maturity in synchrony with oogenesis.

The peak of the reproductive activity occurred between February and April, as suggested by the highest number of oocytes and spermaries (of all stages) and the most rapid growth in the diameter of the oocytes (Fig. 5). This period coincides with high solar irradiance and SST values (Fig. 6A). The solar radiation, or the photosynthetic fraction used by the symbionts, influences the reproductive cycle, as part of the carbon fixed by zooxanthellae is incorporated into planulae production (Rinkevich, 1989). However, the energy allocation seems to occur hierarchically: maintenance, repair, growth, and, finally, reproduction (HARRISON; WALLACE, 1990). So it would be advantageous to the coral that the most energetically costly oocyte reproductive stages should develop when energy production is at its highest, in spring and summer (TANNER, 1996).

The beginning of the gametogenic cycle coincides with the rise in SST (Fig. 6A). This change in SST is usually suggested as an important mechanism to control the beginning of gametogenesis (FADLALLAH， 1985; KRUGER; SCHLEYER, 1998).

In May, only one colony was fertile. In April, we observed spermatozoids ready to be released and empty holes in the mesentery left by the released spermaries, indicating that gamete spawning and oocyte fertilization may occur between April and May.

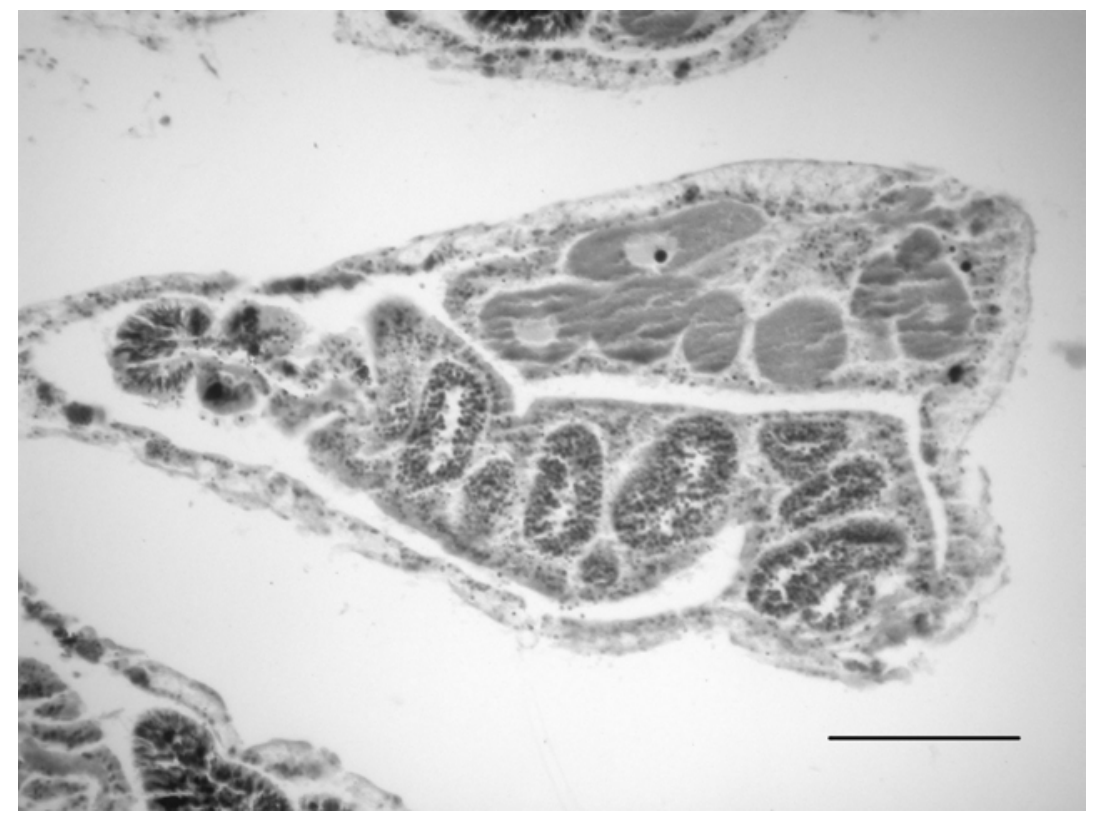

Fig. 3. Gastric loculus almost filled by the gametes in development (scale: $200 \mu \mathrm{m}$ ). 

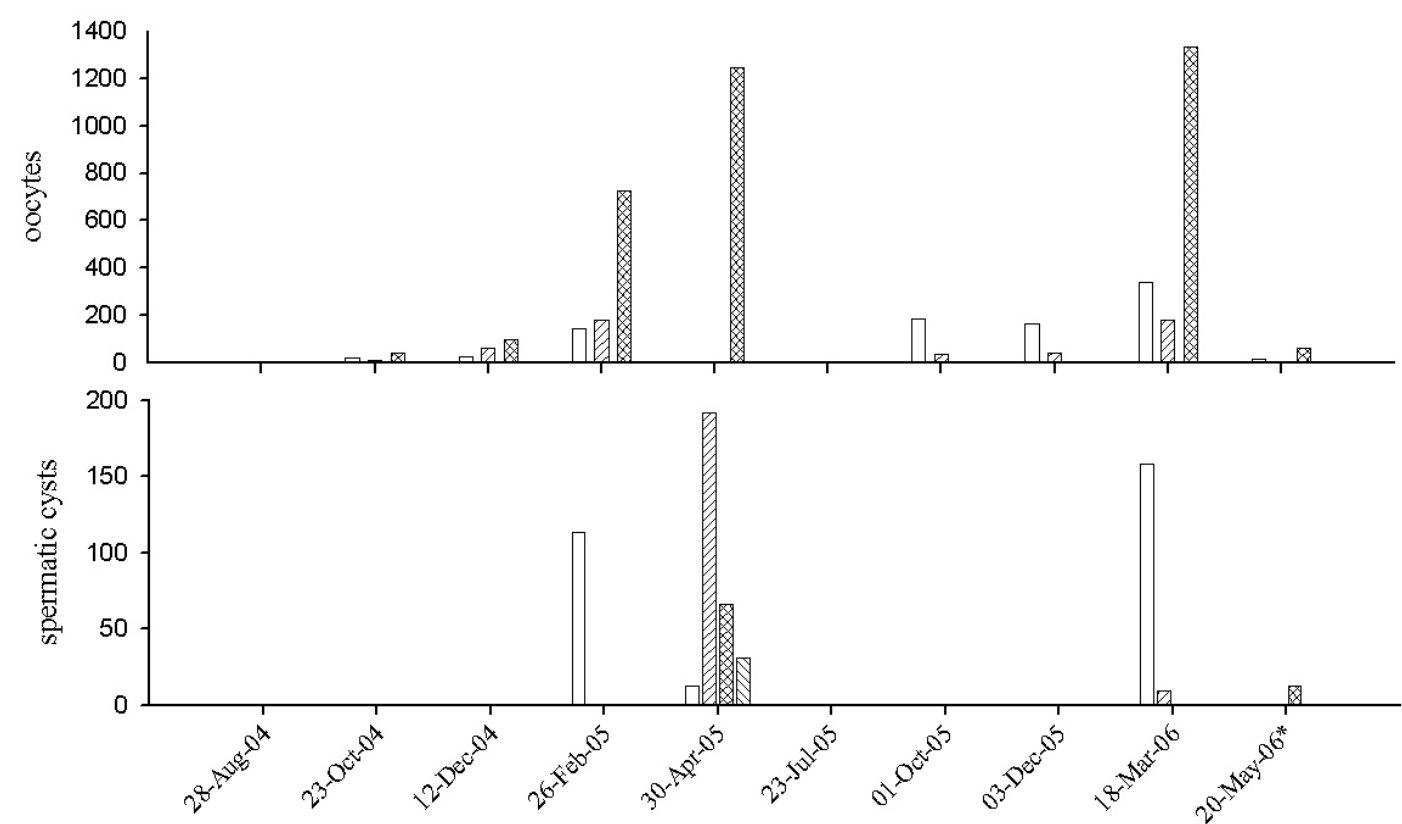

Fig. 4. Total number count of oocyte and spermary stages during the collection period; stage I ( $\square$ ), stage II ( $\square$ ), stage III ( $\mathbf{Q}$ ) and stage IV ( ). * Sample with just one fertile colony.

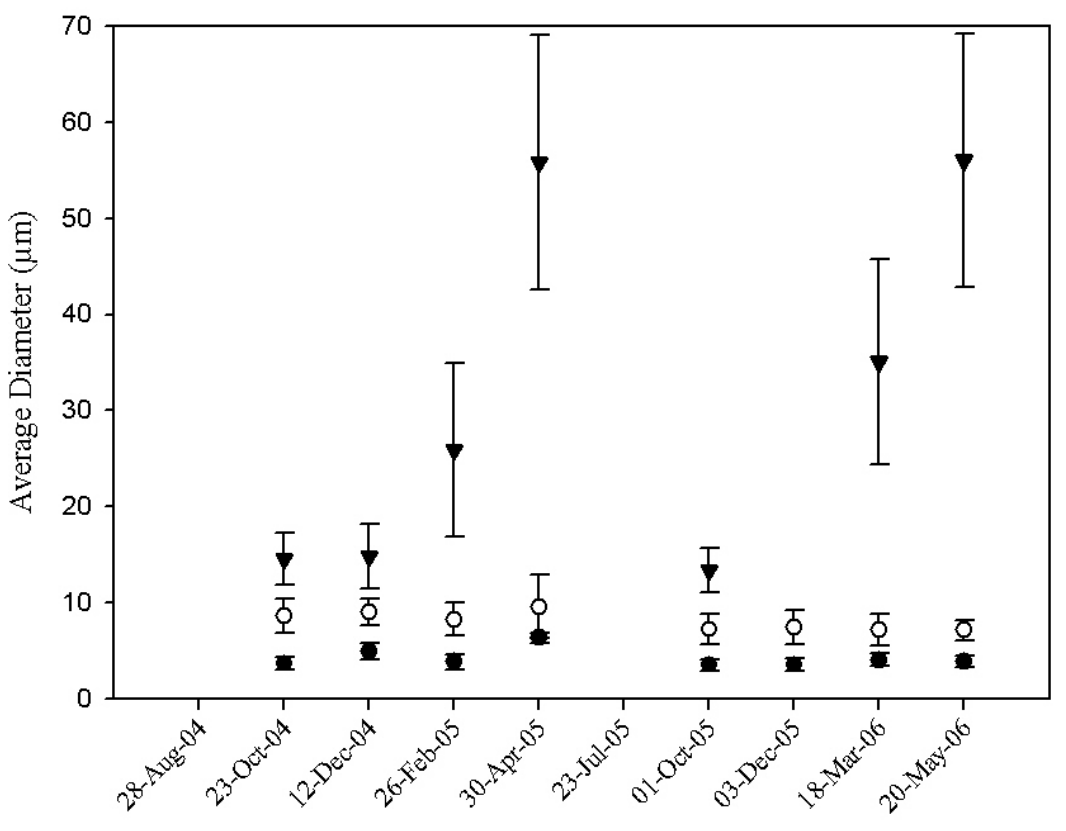

Fig. 5. Average oocyte diameter of stage I $(\bullet)$, stage II (o) and stage III 

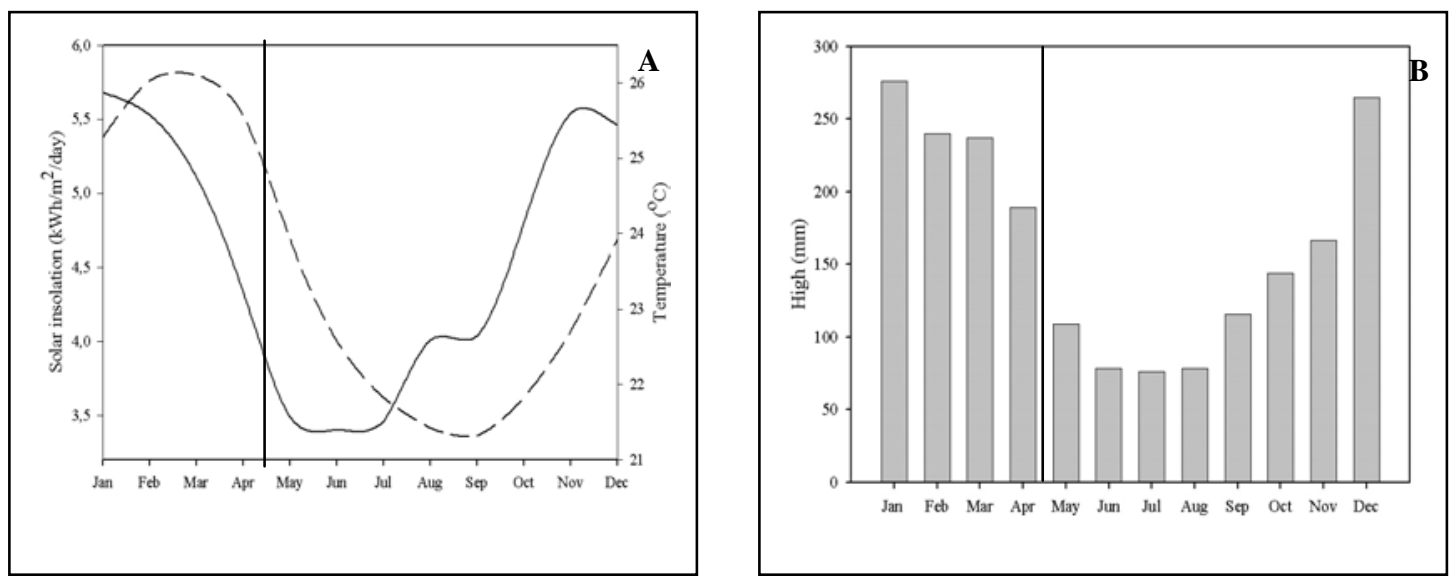

Fig. 6. Environmental parameters: (A) Monthly average solar insolation (1983-1993) (solid line) (NASA), monthly average superficial sea temperature (1985-2006) (dashed line) (NOMADS LAS Server - NOAA); (B) Monthly average precipitation (1961-1990) (INMET). Probable gametes or planulae spawning period (vertical line).

The disappearance of the oocytes and espermatocytes between April and May, suggests that the spawning of gametes or planulae occurs during this interval. This period is characterized by an annual minimal solar insolation and a transitional period between the wet and dry months (Fig. 6). The gametes or planulae spawning at this period may avoid potential damage, when latter, these stages are exposed to high SST and solar insolation at the summer peak (BASSIM et al., 2002; BASSIM; SAMMARCO, 2003) and also avoid periods of salinity reduction and/or water turbidity, which may decrease the pre-settlement phase and increased the mortality rate (VERMEIJ et al., 2006).

The data of this present study suggest that Madracis decactis is a hermaphroditic species whose male and female gametes develop within different mesenteries. The reproductive cycle lasted about seven months. Oogenesis begins in October, while spermatogenesis begins at the end of February, both reaching maturity at the end of April. The peak of reproductive activity (gamete production and maturation) occurred between February and April, when all the polyps were fertile, containing mainly stage III oocytes. No embryos or planulae were observed in the histological sections. The absence of gametes between April and May suggests that the planulae or gametes spawning occurs at this period.

\section{AcKNowledgements}

We thank our buddy divers from Grupo de Mergulho Planeta Oceano, S. Chada (ESEC Tamoios), F. Soares (for the pluviometric data), J. Ricardo (CRESESB), O. Sato (IO-USP), C.E.F. Rocha, R. Lourenço (IB-USP), A. Migotto (CEBIMAR-USP) and M. Barros (UFRJ). We are especially grateful to J.W. Reid and class BIZ5712 (IB USP) for the comments on the manuscript and revision of the English and S. Stampar for his suggestions. We also thank IBAMA for the collection license (no.02027002971/2004). This research was supported by the CNPq (no. 134384/2005-5) by a grant for "PósGraduação, Área de Zoologia (IB-USP)" and CAPES/PROAP 2005-2007.

\section{REFERENCES}

BABCOCK, R. C.; BULL, G. D.; HARRISON, P. L.; HEYWARD, A. J.; OLIVER, J. K.; WALLACE, C. C; WILLIS, B. L. Synchronous spawning of 105 scleractinian coral species on the Great Barrier Reef.. Mar. Biol., v. 90, p. 379-394, 1986.

BASSIM, K. M.; SAMMARCO, P.W. Effects of temperature and ammonium on larval development and survivorship in a scleractinian coral (Diploria strigosa). Mar. Biol., v. 142, p. 241-252, 2003.

BASSIM, K. M.; SAMMARCO, P. W.; SNELL, T. L. Effects of temperature on success of (self and non-self) fertilization and embriogenesis in Diploria strigosa (Cnidaria, Scleractinia). Mar. Biol., v. 140, p. 479-488, 2002.

BRASIL. Ministério do Meio Ambiente. Plano de Manejo do Parque Nacional da Serra da Bocaina. Brasília, DF: $2000 . \quad$ Available from: http://www.paraty.com.br/bocaina/pdf/anexo52.pdf. Accessed: 25 May 2007.

CALDERON, E. M.; CASTRO, C. B.; PIRES, D. O. Natação, assentamento e metamorfose de plânulas do coral Favia gravida Verril, 1868 (Cnidaria, Scleractinia). Bolm Mus. nac., n.s. Zool., v. 429, p. 1-12, 2000.

CASTRO, B. T.; PIRES, D. O. Reproductive biology of Madracis decactis (Lyman, 1859) (Cnidaria, Scleractinia) from southern Bahia reefs, Brazil. Arq. Mus. nac., v. 64, n. 1, p. 19-27, 2006. 
CASTRO, C.B.; PIRES, D.O. Brazilian coral reefs: what we already know and what is still missing. Bull. mar. Sci., v. 69 , n. 2 , p. $357-371,2001$.

FADLALLAH, Y. H. Reproduction in the coral Pocillopora verrucosa on the reefs adjacent to the industrial city of Yanbu (Red Sea, Saudi Arabia). In: CORAL REEF CONGR., 5. Proc..., v. 4, p. 313-318, 1985.

FRANCINI, C. L. B.; CASTRO, C. B.; PIRES, D. O. First record of a reef coral spawning event in the western South Atlantic. Reprod. Develop., v. 42, n.1, p. 17-19, 2002.

GLYNN, P. W.; GASSMAN, N. J.; EAKIN, C. M.; CORTÉS, J.; SMITH, D. B.; GUZMAN, H. M. Reef coral reproduction in the eastern Pacific: Costa Rica, Panama, and Galapagos Islands (Ecuador). I. Pocilloporidae. Mar. Biol., v. 109, p. 355-368, 1991.

GLYNN, P. W.; COLLEY, S. B.; EAKIN, C. M.; SMITH, D B.; CORTÉS, J.; GASSMAN, N. J.; GUZMÁN, H. M.; DEL ROSARIO, J. B.; FEINGOLD, J. S. Reef coral reproduction in the eastern Pacific: Costa Rica, Panamá, and Galápagos Islands (Ecuador). II. Poritidae. Mar. Biol., v.118, p. 191-208, 1994.

HARRIOTT, V. J. Reproductive seasonality, settlement, and post-settlement mortality of Pocillopora damicornis (Linnaeus), at Lizard Island, Great Barrier Reef. Coral Reefs, v. 2, p. 151-157, 1983.

HARRISON, P. L. Sexual characteristics of scleractinian corals: systematic and evolutionary implications. In: INT. CORAL REEF CONGR., 5. Proc....v. 4, p. 337342,1985

HARRISON, P. L.; WALLACE, C. C. Reproduction, dispersal and recruitment of scleractinian corals. In: DUBINSKY, Z. (Ed.). Ecosystems of the World 25 Amsterdam: Elsevier, 1990. p. 133-196.

KOJIS, B. L.; QUINN, N .J. Aspects of sexual reproduction and larval development in the shallow water hermatypic coral, Goniastrea australiensis (Edward and Haime, 1857). Bull. mar. Sci., v. 31, n. 3, p. 558-573, 1981.

KRUGER, A.; SCHLEYER, M. H. Sexual reproduction in the coral Pocillopora verrucosa (Cnidaria: Scleractinia) in KwaZulu-Natal, South Africa. Mar. Biol., v. 132, p. 703-710, 1998.

LABOREL, J. L. Madréporaires et hydrocoralliaires récifaux des cotes brésiliennes: Systematique, écologie, répartition verticale et géographique. Campagne de la Calypso au large des cotes atlantiques de l'Amérique du Sud. Anns Inst. Océanogr. Paris, v. 47, n. 9, p. 15-229, 1969/70.

LEÃO, Z.M.A.N.; KIKUCHI, R. P.;TESTA, V. Coral and coral reefs of Brazil. In: CORTÉS, J. (Ed.). Latin American coral reefs. Amsterdam: Elsevier. 2003. p. 952, 2003.

LINS DE BARROS, M.; PIRES, D. O.; CASTRO, C. B. Sexual reproduction of the Brazilian reef coral Siderastrea stellata Verril 1868 (Anthozoa, Scleractinia). Bull. mar. Sci., v. 73, n. 3, p. 713-724, 2003.

MENDES, J. M.; WOODLEY, J. D. Timing of reproduction in Montastrea annularis: relationship to environmental variables. Mar. Ecol. Prog. Ser., v. 227, p. 241-251, 2002.

NEVES, E. G.; PIRES, D. O. Sexual reproduction of Brazilian coral Mussismilia hispida. Coral Reefs, v. 21, p. 161-168, 2002.
NEVES, E. G.; SILVEIRA, F. L. D. Release of planulae larvae, settlement and development of Siderastrea stellata Verrill, 1868 (Anthozoa, Scleractinia). Hydrobiologia, v.501, p. 139-147, 2003.

OLIVER, J. K.; BABCOCK, R. C.; HARRISON, P. L.; WILLIS, B. L. Geographic extent of mass coral spawning: clues to ultimate causal factors. In: INT. CORAL REEF SYMP., 6, Proc...., v. 2, p. 803-810, 1988.

PENLAND, L.; KOULECHAD, J.; IDIP, D.; VAN WOESIK, R. Coral spawning in the western Pacific Ocean is related to solar insolation: evidence of multiple spawning events in Palau. Coral Reefs, v. 23, p. 133140, 2004.

PIRES, D. O.; CAPARELLI, A. C. Biologia reprodutiva de Porites astreoides Lamarck, 1816 (Cnidaria, Scleractinia) do Complexo Recifal dos Abrolhos, BA, Brasil. Bolm Mus. nac., v. 484, p. 1-12, 2002.

PIRES, D. O.; CASTRO, C. B.; RATTO, C. C. Reef coral reproduction in the Abrolhos Reef Complex, Brazil: the endemic genus Mussismilia. Mar. Biol., v. 135, p. 463471, 1999.

PIRES, D. O.; CASTRO, C. B.; RATTO, C. C. Reproduction of the solitary coral Scolymia wellsi Laborel (Cnidaria, Scleractinia) from the Abrolhos Reef Complex, Brazil. In: INT. CORAL REEF SYMP., 9. Proc. ..., v. 1, p. 381-384, 2002.

RINKEVICH, B. The contribution of photosynthetic products to coral reproduction. Mar. Biol., v. 101, p. 259-263, 1989

SIER, C.J.S.; OLIVE, P.J.W. Reproduction and reproductive variability in the coral Pocillopora verrucosa from Republic of Maldives. Mar. Biol., v. 118, p. 713-722, 1994.

SOONG, K. Sexual reproductive patterns of shallow-water reef corals in Panama. Bull. mar. Sci., v. 49, n. 3, p. 832-846, 1991

SOARES, F. S.; FRANCISCO, C. N.; CARVALHO, C. N. D. Análise dos fatores que influenciam a distribuição espacial da precipitação no litoral sul fluminense, RJ. In: SIMPÓSIO BRASILEIRO DE SENSORIAMENTO REMOTO, 12. Anais ..., p. 3365-3370, 2005.

STIMSON, J.S. Mode and timing of reproduction of some common hermatypic corals of Hawaii and Enewetak. Mar. Biol., v. 48, p. 173-184, 1978.

SZMANT-FROELICH, A. M.; YEVICH, P.; PILSON, E. Q.Gametogenesis and early development of the temperate coral Astrangia danae (Anthozoa: Scleractinia). Biol. Bull., v. 158, p. 257-269, 1980.

SZMANT-FROELICH, A. M; REUTTER, M.; RIGGS, L. Sexual reproduction of Favia fragum (Esper): lunar patterns of gametogenesis, embriogenesis and planulation in Puerto Rico. Bull. mar. Sci., v. 37, n. 3, p. 880-892, 1985

TANNER, J.E. Seasonality and lunar periodicity in the reproduction of Pocilloporid corals. Coral Reefs, v. 15, p. 59-66, 1996.

VAN WOESIK, R., LACHARMOISE, F.; KÖKSAL, S. Annual cycles of solar insolation predict spawning times of Caribbean corals. Ecol. Letters, v. 9, p. 390-398, 2006 
VERMEIJ, M. J. A.; SAMPAYO, E.; BRÖKER, K.; BAK. R. P. M. Variation in the planulae release of closely related coral species. Mar. Ecol. Prog. Ser., v. 247, p. 75-84, 2003.

VERMEIJ, M.J.A.; SAMPAYO, E.; BRÖKER, K.; BAK, R.P.M. The reproductive biology of closely related coral species: gametogenesis in Madracis from the southern Caribbean. Coral Reefs, v. 23, p. 206-214, 2004.

VERMEIJ, M. J .A.; FOGARTY, N. D.; MILLER, M. W. Pelagic conditions affect larval behavior, survival and settlement pattern in the Caribbean coral Montastrea faveolata. Mar. Ecol. Prog. Ser., v. 310, p. 119-128, 2006.
WARD, S. Evidence for broadcast spawning as well as brooding in the scleractinian coral Pocillopora damicornis. Mar. Biol., v. 112, p. 641-646, 1992.

(Manuscript received 12 September 2007; revised 24 January 2008; accepted 15 August 2008) 